\title{
EXTRA-ABDOMINAL DESMOID TUMOR: ANALYSIS OF 23 CONSECUTIVE CASES IN A SINGLE INSTITUTION
}

\section{TUMOR DESMOIDE EXTRA-ABDOMINAL: ANÁLISE DE 23 CASOS CONSECUTIVOS EM UMA ÚNICA INSTITUIÇÃO}

\author{
Juan Pablo Zumárraga ${ }^{1}$, Brian Guilherme Monteiro Marta Coimbra ${ }^{2}$, Felipe Gonçalves dos Santos ${ }^{1}$, André Mathias Baptista ${ }^{1}$, \\ Marcelo Tomio Kohara ${ }^{1}$, Olavo Pires de Camargo $0^{1-3}$
}

1. Orthopedic Oncology Group, Instituto de Ortopedia e Traumatologia, Hospital das Clinicas HCFMUSP, Faculdade de Medicina, Universidade de São Paulo, São Paulo, SP, Brazil. 2. Instituto de Ortopedia, Hospital das Clinicas HCFMUSP, Faculdade de Medicina, Universidade de São Paulo, São Paulo, SP, Brazil.

3. Department of Orthopedics and Traumatology, Faculdade de Medicina, Universidade de São Paulo, São Paulo, SP, Brazil.

\section{ABSTRACT}

Objective: Extra-abdominal desmoid tumor (EDT) is a rare condition, caused by proliferation of fibroblasts. Despite being a benign tumor, it is locally aggressive and has unpredictable clinical behavior. The objective of this study is to present the clinical outcomes of patients with EDT treated surgically between 1995 and 2016. Methods: This is a retrospective series of 23 patients with histopathological diagnosis of EDT that underwent surgery at the orthopedic oncology service of our hospital. The information was obtained from the institute's clinical and pathology reports. Results: A total of 223 medical records with histopathological reports were evaluated. Only 23 cases of EDT were included in the present study. The mean age was 22.5 years. Twelve (52.2\%) patients had the tumor on the lower limbs, seven (30.4\%) on the upper limbs and four (17.4\%) cases were reported on the back. Five $(21.7 \%$ ) patients had tumors measuring less than $5 \mathrm{~cm}$, while eighteen (78.3\%) patients had tumors measuring more than 5 $\mathrm{cm}$. All patients underwent surgery as the definitive treatment in our institute. Twelve (52.2\%) cases presented negative margins (NM) and eleven (47.8\%) cases had positive margins (PM). Local recurrence (LR) occurred in eleven (47.8\%) patients. Conclusion: Impairment of the surgical margin was the only prognostic factor found for LR of EDT. Level of Evidence IV, Case Series.

Keywords: Fibromatosis, aggressive. Surgical oncology. Local neoplasm recurrence. Margins of excision. Prognosis.

\section{RESUMO}

Objetivo: O tumor desmoide extra-abdominal (TDE) é raro, formado por proliferação de fibroblastos. Apesar de ser um tumor benigno, é localmente agressivo e tem comportamento clínico imprevisível. O objetivo desta pesquisa é apresentar os resultados clínicos obtidos nos pacientes com TDE, tratados cirurgicamente entre 1995 e 2016. Métodos: Trata-se de uma série retrospectiva de 23 pacientes com diagnóstico anatomopatológico de TDE, tratados cirurgicamente no serviço de oncologia ortopédica de nosso hospital. A informação foi obtida dos relatos clínicos e patológicos do instituto. Resultados: Um total de 223 prontuários com relato anatomopatológico foi revisado. Apenas 23 casos de TDE foram incluídos no presente estudo. A média de idade foi de 22,5 anos. Doze (52,2\%) casos se localizaram nos membros inferiores, sete $(30,4 \%)$ casos nos membros superiores e quatro $(17,4 \%)$ casos se localizaram no dorso. Cinco (21,7\%) casos tinham tamanho $<5 \mathrm{~cm}$ e 18 (78,3\%) casos tinham tamanho $>5 \mathrm{~cm}$. Todos os pacientes receberam tratamento cirúrgico como terapia definitiva no instituto. Doze $(52,2 \%)$ casos apresentaram margens livres (ML) e onze $(47,8 \%)$ casos tinham margens comprometidas (MC). A recorrência local (RL) ocorreu em onze (47,8\%) pacientes. Conclusão: O comprometimento da margem cirúrgica foi o único fator de prognóstico encontrado para a RL do TDE. Nível de Evidência IV, Série de Casos.

Descritores: Fibromatose agressiva. Cirurgia oncológica. Recidiva local de neoplasia. Margens de excisão. Prognóstico.

Citation: Zumárraga JP, Coimbra BGMM, Santos FG, Baptista AM, Kohara MT, Camargo OP. Extra-abdominal desmoid tumor: analysis of 23 consecutive cases in a single institution. Acta Ortop Bras. [online]. 2018;26(4):244-7. Available from URL: http://www.scielo.br/aob.

\section{INTRODUCTION}

Extra-abdominal desmoid tumors (EDT) are a rare condition caused by the proliferation of fibroblasts. Although the tumor is benign, it is locally aggressive, and its unpredictable clinical behavior leads to disagreement regarding its treatment.1,2 According to the World Health Organization (WHO), EDT is defined as a monoclonal proliferation of fibroblasts that affects deep soft tissues. It is characterized by infiltrative growth and a tendency toward local recurrence (LR). It does not present distant metastasis (DM). ${ }^{3}$ EDT can affect any part of the body, but appears more frequently on the limbs and trunk (Figure 1 ). These tumors are rare, with an incidence of 2-4 cases/1,000,000

\section{All authors declare no potential conflict of interest related to this article.}




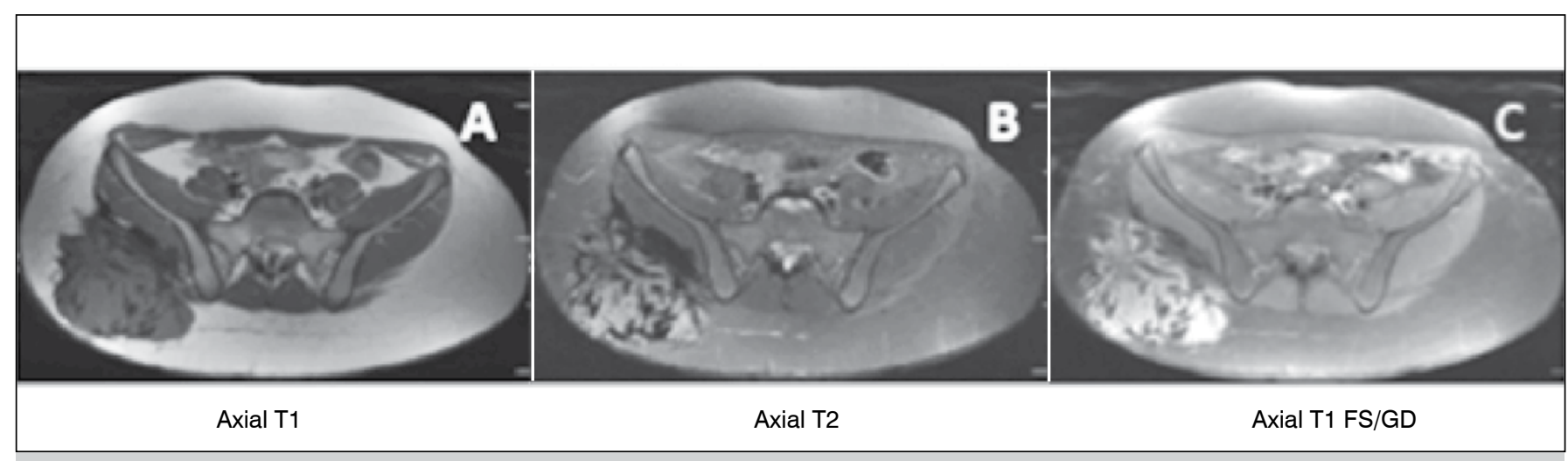

Figure 1. MRI: Desmoid tumor in the right gluteal area.

individuals in global statistics. Onset ranges from subjects in their 20 s to their 70s, with a higher incidence in subjects in their 40 s or thereabouts. ${ }^{4-6}$ The treatment of choice is based on resection surgery with negative margins (NM). Clinical surveillance may be used in duly selected cases where constant outpatient follow-up is maintained. ${ }^{7}$ In view of the local characteristics of EDT, resection with NM represents a challenge to the surgeon. The pattern of growth with projections and the impossibility of distinguishing the capsule during the surgical procedure increase the risk of involvement of the surgical margins, which are frequently mentioned in pathology reports. ${ }^{8-11}$ Therefore adjuvant radiotherapy is a method of choice to avoid LR. When this occurs, it can be isolated or multiple, can acquire a more aggressive biological activity and spread locally. ${ }^{12-14}$ If resection is not possible, pharmacological treatment may be indicated. Pharmacological options include anti-hormonal agents (e.g. tamoxifen), nonsteroidal anti-inflammatory drugs (e.g. celecoxib), and conventional chemotherapy (CT) ${ }^{15,16}$ Ultimately, treatment of the disease should be multidisciplinary, focusing on the quality of life and function of the affected patient. ${ }^{17}$ The purpose of this research is to present the clinical results obtained in patients with EDT treated at our institution.

\section{MATERIALS AND METHODS}

The study was approved by the Institutional Review Board of HCFMUSP under number 1174. It is a cross-sectional retrospective study in which 23 medical records of patients diagnosed with EDT by the IOT-HC-FMUSP Orthopedic Oncology Group covering the period from 1995 to 2016 were used. We reviewed 223 medical records, 200 of which were excluded due to lack of data. All patients included in this study received surgical treatment. Age, sex, laterality, date of diagnosis, tumor size, type of surgery and postoperative outpatient follow-up were acquired from the medical records (Table 1). The histological diagnosis was made by the pathologists of the institute. The patients' characteristics were described using absolute and relative frequencies, and their age was also described using mean and standard deviation. ${ }^{18}$ The mean disease-free survival with the respective intervals was estimated with 95\% confidence according to characteristics of interest. The mean times were estimated when it was not possible to estimate the median time using the Kaplan-Meier estimator, ${ }^{19}$ and times were compared between the categories of characteristics using log-rank tests. ${ }^{19}$ The hazard ratios (HR) of LR-free time were estimated between the categories with the respective 95\% confidence intervals using bivariate Cox regression models. ${ }^{19}$ The tests were conducted with a significance level of $5 \%$.
Table 1. Description of patient demographics.

\begin{tabular}{|c|c|c|}
\hline Variable & Frequency & $\%$ \\
\hline \multicolumn{3}{|l|}{ Sex } \\
\hline Female & 12 & 52.2 \\
\hline Male & 11 & 47.8 \\
\hline \multicolumn{3}{|l|}{ Age $^{*}$} \\
\hline$\leq 20$ years & 10 & 45.5 \\
\hline$>20$ years & 12 & 54.5 \\
\hline Mean (SD) & $22.5(11.9)$ & \\
\hline \multicolumn{3}{|l|}{ Tumor Site } \\
\hline Lower Limb & 12 & 52.2 \\
\hline Upper Limb & 7 & 30.4 \\
\hline Back & 4 & 17.4 \\
\hline \multicolumn{3}{|l|}{ Laterality* } \\
\hline Right & 10 & 47.6 \\
\hline Left & 11 & 52.4 \\
\hline \multicolumn{3}{|l|}{ Margin } \\
\hline Negative & 12 & 52.2 \\
\hline Positive & 11 & 47.8 \\
\hline \multicolumn{3}{|l|}{ Tumor Size } \\
\hline$<5 \mathrm{~cm}$ & 5 & 21.7 \\
\hline$\geq 5 \mathrm{~cm}$ & 18 & 78.3 \\
\hline \multicolumn{3}{|l|}{ Recurrence } \\
\hline No & 12 & 52.2 \\
\hline Yes & 11 & 47.8 \\
\hline Total & 23 & 100 \\
\hline
\end{tabular}

\section{RESULTS}

A total of 223 medical records with pathology reports were reviewed for this study. Only 23 cases of EDT were included in the present study. The mean age was 22.5 years. Twelve patients were female (52.2\%) and eleven male (47.8\%). The left side was affected most often with 11 (52.4\%) cases, while there were 10 right-sided cases (47.6\%) and two cases involving the midline back. Twelve (52.2\%) cases were located in the lower limbs, seven (30.4\%) cases in the upper limbs, and four (17.4\%) cases were located on the back. Regarding tumor size, five (21.7\%) cases measured $<5 \mathrm{~cm}$ and $18(78.3 \%)$ cases measured size $>5 \mathrm{~cm}$. All patients received surgical treatment as definitive therapy at the institute. The surgery of choice for all patients was surgical resection with NM. The histopathology reports listed twelve 
(52.2\%) cases with NM and eleven (47.8\%) cases with PM. LR occurred in eleven (47.8\%) patients. Only the surgical margins influenced the disease-free survival of patients with EDT (Figure 2). Patients with PM presented a 90-fold higher risk of LR when compared to patients with NM ( $p<0.001)$ (Table 2).

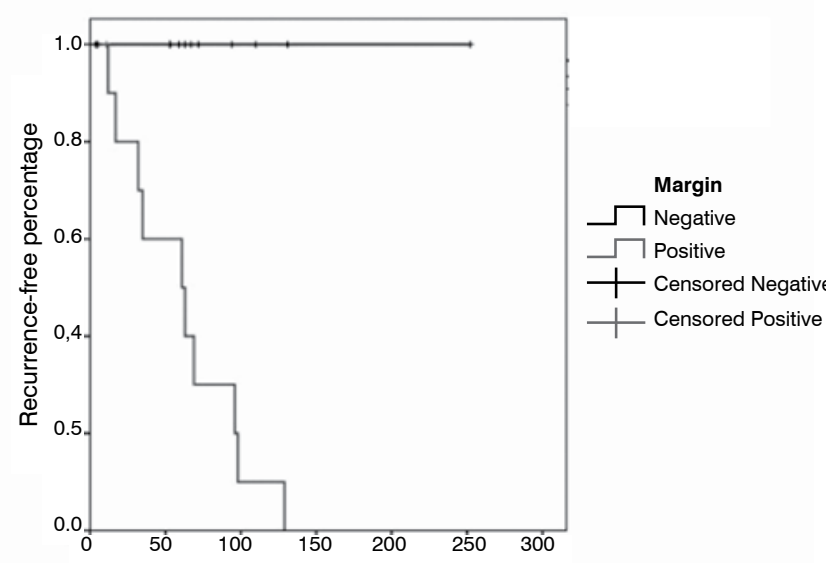

Recurrence-free survival (months)

Figure 2. Kaplan-Meier plot of local recurrence according to margin

\section{DISCUSSION}

The literature presents an extensive list of publications on EDT. Most of the published studies are retrospective series and case reports. ${ }^{2,6}$ This study was no exception: we analyzed 23 consecutive cases over 16 years. We did not find many studies addressing EDT in our field. The mean age in our study was 22.5 years, which coincides with that described in the literature. ${ }^{7,9}$ In bibliographical terms, EDT predominates slightly in female subjects. ${ }^{1}$ In this study we also observed female predominance (52.2\%). Published studies indicate that EDT occurs mainly in the abdomen. ${ }^{14,15,20}$ This data cannot be compared as the study was conducted at an orthopedic institute. Therefore, we found widespread wide predominance of limb involvement, with a rate of $82.6 \%$. As defined in the literature, the mean preoperative size ranges between 8 and $12 \mathrm{~cm} .{ }^{21}$ In our study the size varied a great deal, yet most cases involved tumors $>5 \mathrm{~cm}$, a fact similar to the published data. We also reported a PM rate of $47.8 \%$. This data is not commonly reported in numerical values in the literature. One of the few studies with this data reported a rate of $42.5 \% .{ }^{22}$ Again, this finding is similar to that of our research. The main complication of EDT is LR, with rates ranging between 40 and $60 \%{ }^{17,21,23}$ Our study found a LR rate of $47.8 \%$, again coinciding with the literature. The mean patient follow-up time was 98 months. Finally, we report that surgical margin impairment is directly related to the decrease in disease-free survival of the patient presenting with this tumor.

\section{CONCLUSIONS}

Surgical margin impairment was the only prognostic factor found for EDT LR.

Table 2. Mean disease-free survival according to the information resulting from comparative tests.

\begin{tabular}{|c|c|c|c|c|c|c|c|c|c|c|}
\hline \multirow[t]{2}{*}{ Variable } & \multirow{2}{*}{$\begin{array}{c}\text { Median Time } \\
\text { (months) }\end{array}$} & \multicolumn{2}{|c|}{$\mathrm{Cl}(95 \%)$} & \multirow[t]{2}{*}{ Recurrence } & \multirow[t]{2}{*}{ Total } & \multirow[t]{2}{*}{$\%$} & \multirow[t]{2}{*}{ HR } & \multicolumn{2}{|c|}{$\mathrm{Cl}(95 \%)$} & \multirow[t]{2}{*}{$p$} \\
\hline & & Lower & Upper & & & & & Lower & Upper & \\
\hline Sex & & & & & & & & & & 0.24 \\
\hline Male* $^{*}$ & 170.7 & 98.1 & 243.3 & 3 & 11 & 27.3 & 0.43 & 0.11 & 1.69 & \\
\hline Age & & & & & & & & & & 0.7 \\
\hline Tumor Site & & & & & & & & & & 0.058 \\
\hline Lower Limb & 63 & 31.7 & 94.3 & 7 & 12 & 58.3 & 1 & & & \\
\hline Upper Limb * & 183.3 & 107.8 & 258.7 & 2 & 7 & 28.6 & 0.11 & 0.01 & 0.91 & \\
\hline Back & 69 & $\#$ & $\#$ & 1 & 4 & 25 & 0.86 & 0.1 & 7.25 & \\
\hline Laterality & & & & & & & & & & 0.344 \\
\hline Negative & 252 & $\#$ & $\#$ & 0 & 12 & 0 & 1 & & & \\
\hline Positive & 61 & 17.6 & 104.4 & 10 & 11 & 90.9 & 88.34 & 0.5 & 15498.91 & \\
\hline Tumor Size & & & & & & & & & & 0.789 \\
\hline$<5 \mathrm{~cm}$ & 98 & 52.8 & 143.2 & 3 & 5 & 60 & 1 & & & \\
\hline$\geq 5 \mathrm{~cm}$ & 96 & 39.4 & 152.6 & 7 & 18 & 38.9 & 1.21 & 0.31 & 4.72 & \\
\hline Total & 98 & 58 & 138 & 10 & 23 & 43.5 & & & & \\
\hline
\end{tabular}

*Mean recurrence-free survival. \#Cannot be estimated.

AUTHORS' CONTRIBUTIONS: Each author made significant individual contributions to this manuscript. JPZ (0000-0001-5941-7714)*, BGMMC (00000001-5461-3644)*, FGS (0000-0002-6854-6072)*, AMB (0000-0002-0830-4602)* , MTK (000-0003-3384-7905)*, OPC (0000-0002-1128-7292)*, were the main contributors in writing this work. JPZ participated in: concept, research, design, writing, and analysis; BGMMC participated in research, design and data collection; FGS participated in: concept, research, writing and data collection; AMB participated in concept, research, writing and analysis; MTK participated in research, design and data collection; OPC participated in concept, writing and analysis. * ORCID (Open Researcher and Contributor ID). 


\section{REFERENCES}

1. van Broekhoven DL, Deroose JP, Bonvalot S, Gronchi A, Grünhagen DJ, Eggermont AM, et al. Isolated limb perfusion using tumour necrosis factor and melphalan in patients with advanced aggressive fibromatosis. $\mathrm{Br} \mathrm{J}$ Surg. 2014;101(13):1674-80.

2. Houdek MT, Rose PS, Kakar S. Desmoid tumors of the upper extremity. J Hand Surg Am. 2014;39(9):1761-5.

3. Eastley N, Aujla R, Silk R, Richards CJ, McCulloch TA, Esler CP, et al. Extraabdominal desmoid fibromatosis--a sarcoma unit review of practice, long term recurrence rates and survival. Eur J Surg Oncol. 2014;40(9):1125-30.

4. Hori A, Murata S, Kono M, Maeda M, Sueyoshi S, Seki A, et al. [Effect of transarterial chemoembolization for recurrent desmoid tumor - a case report.] Gan To Kagaku Ryoho. 2013;40(9):1259-62.

5. Prodinger PM, Rechl H, Keller M, Pilge H, Salzmann M, von Eisenhart-Rothe $\mathrm{R}$, et al. Surgical resection and radiation therapy of desmoid tumours of the extremities: results of a supra-regional tumour centre. Int Orthop. 2013;37(10):1987-93.

6. Maher J, Smith DA, Parker WL. Desmoid tumor of the hand: a case report. Ann Plast Surg. 2014;73(4):390-2.

7. Oweis Y, Lucas DR, Brandon CJ, Girish G, Jacobson JA, Fessell DP. Extra-abdominal desmoid tumor with osseous involvement. Skeletal Radiol. 2012;41(4):483-7.

8. Stollwerck PL, Namdar T, Bartscher T, Lange T, Stang FH, Kujath P, et al. A rare desmoid tumor of the shoulder--excision, implantation of brachytherapy applicators and wound closure by pedicle musculus latissimus dorsi flap. Ger Med Sci. 2011;9:Doc04.

9. Sciallis GF, Sciallis AP. Becker nevus with an underlying desmoid tumor: a case report and review including Mayo Clinic's experience. Arch Dermatol. 2010;146(12):1408-12.

10. Solanki NS, Macfarlane PL, Marshall NJ. Images for surgeons. An extra-abdominal desmoid tumour in a young woman. ANZ J Surg. 2010;80(10):743-4.

11. Jakowski JD, Mayerson J, Wakely PE Jr. Fine-needle aspiration biopsy of the distal extremities: a study of 141 cases. Am J Clin Pathol. 2010;133(2):224-31. 12. Couto-Gonzalez I, Brea-Garcia B, Taboada-Suárez A, González-Álvarez E. Aggressive Dupuytren's diathesis in a young woman. BMJ Case Rep. 2010;2010.

13. Gallucci GL, Boretto JG, De Carli P. Desmoid tumor of the forearm. Reconstructive surgery and functional result. Chir Main. 2009;28(5):326-9.

14. Shido $Y$, Nishida $Y$, Nakashima $H$, Katagiri $H$, Sugiura $H$, Yamada $Y$, et al Surgical treatment for local control of extremity and trunk desmoid tumors. Arch Orthop Trauma Surg. 2009;129(7):929-33.

15. Altmann S, Lenz-Scharf O, Schneider W. [Therapeutic options for aggressive fibromatosis]. Handchir Mikrochir Plast Chir. 2008;40(2):88-93.

16. Engelhardt TO, Jeschke J, Piza-Katzer $\mathrm{H}$. [About the self-reported quality of life after amputation of the hand in patients with upper extremity tumors]. Handchir Mikrochir Plast Chir. 2008;40(1):23-30.

17. Ozger H, Eralp L, Toker B, Ağaoğlu F, Dizdar Y. [Evaluation of prognostic factors affecting recurrences and disease-free survival in extra-abdominal desmoid tumors]. Acta Orthop Traumatol Turc. 2007;41(4):291-4.

18. Kirkwood BR, Sterne JA. Essential medical statistics. 2nd ed. Massachusetts: Blackwell Science; 2006

19. Kleinbaum DG. Survival analysis: a self-learning text. New York: Springer; 1996.

20. Sakamaki Y, Kido T, Yasukawa M, Fujiwara T, Kuwae K, Maeda M. Wide resection of the upper right hemithorax combined with amputation of the right arm for a recurrent desmoid tumor. Jpn J Thorac Cardiovasc Surg. 2006;54(8):338-41.

21. Ballo MT, Zagars GK, Pollack A, Pisters PW, Pollack RA. Desmoid tumor: prognostic factors and outcome after surgery, radiation therapy, or combined surgery and radiation therapy. J Clin Oncol. 1999;17(1):158-67.

22. Duggal A, Dickinson IC, Sommerville S, Gallie P. The management of extra-abdominal desmoid tumours. Int Orthop. 2004;28(4):252-6.

23. Wang YF, Guo W, Sun KK, Yang RL, Tang XD, Ji T, et al. Postoperative recurrence of desmoid tumors: clinical and pathological perspectives. World $\mathrm{J}$ Surg Oncol. 2015;13:26. 